\title{
Comparative study of analgesic effect of Ondansetron and Aspirin in experimentally induced pain models in animals.
}

\author{
Bharathi Uppu ${ }^{1}$, Ashalatha Muppur ${ }^{2}$, Vasundhara Devi.B ${ }^{3}$ \\ 1)(Assistant Professor, Dept of Pharmacology, S.V. Medical college, NTRUHS, India) \\ 2)(Assistant Professor, , Dept of Pharmacology, S.V. Medical college, NTRUHS, India) \\ 3)(HOD,Dept of pharmacology,s.v.medical college,NTRUHS,India)
}

\begin{abstract}
:
Background: In this era, there is a need for new analgesics. Ondansetron is an established antiemetic and Aspirin is a standard and potent analgesic drug. Ondansetron is an 5HT antagonist and aspirin is an non steroidal anti inflammatory drug.
\end{abstract}

Aim \& Objective: To compare the analgesic effect of Ondansetron and Aspirin in experimentally induced pain models in animals.

Materials and MethodS: The analgesic effect of Ondansetron and Aspirin was evaluated in swiss albino mice $(n=8)$. The methods used to produce pain models of animals were chemical method(by intraperitonial injection of $.6 \%$ of acetic acid), mechanical method(by tail clip method) and radiant heat method(by analgesiometer).

Results: The analgesic effect of Ondansetron was found to be more than Aspirin in chemically induced pain models $(P<0.05$.) Aspirin has better analgesic effect than ondansetron in mechanically induced pain $(P<$ 0.05). Ondansetron has no analgesic effect in pain induced by radiant heat method while aspirin is a good analgesic in this method.

Conclusion: Ondansetron showed superior analgesic effect than that of aspirin in chemically induced pain .

Key words: Aspirin, Analgesic effect, Ondansetron, Pain models, writhing movements.

\section{Introduction:}

One of the greatest services a doctor can do to his patients is to acquire skill in the management of pain. Pain is experienced as having qualities such as sharp, throbbing, dull, nauseating, burning and shooting. Pain receptors are free nerve endings. There are mechanical, thermal and chemical pain receptors. Nociceptor A and $\mathrm{C}$ fibers mediate fast and slow pain. Thin myelinated A fibers transmit signals at the rate of 6 to $30 \mathrm{~m}$ per second. They mediate fast pain. It includes mechanical and thermal pain. Slow pain mediated by slower, unmyelinated type $\mathrm{C}$ pain fibers that send signals at the rate of 0.5 to $2 \mathrm{~m}$ per second. Chemical pain is of slow pain type.

Serotonin is one of the neurotransmitters involved in nociception. Serotonin antagonist may reduce pain. 5 HT3 receptors are present on capsaicin sensitive primary afferent terminals in the superficial dorsal horn of the spinal cord. Animal data would suggest that prior administration of Ondansetron. prevents the increase in pain and sensitivity that accompanies a peripheral stimulus. 5 HT3 antagonism by ondansetron could affect analgesia.

Present study compares Ondansetron with standard drug Aspirin for its analgesic ${ }^{(1)}$ property mainly in chemical, mechanical and thermally induced pain in animals.Non steroidal anti inflammatory drugs (NSAIDS) ${ }^{(2)}$ are drugs with analgesic, antipyretic, and anti inflammatory effects .Prominent members of this group of drugs are aspirin, ibuprofen, diclofenac, aceclofenac.Beginning in 1829 with the isolation of salicylic acid from the folk remedy willowbark NSAIDS have become an important part of the pharmaceutical treatment of pain.

Ondansetron $^{(3)}$ is a serotonin $5 \mathrm{HT}_{3}$ receptor antagonist introduced in 1990s . There are seven types of $5 \mathrm{HT}$ receptors. A high density of $5 \mathrm{HT}$ receptors are found in the area postrema and nucleus tractus solitarious most likely on vagus nerve terminals.

Pharmacopoeial description: A white to half white powder, sparingly soluble in water, alcohol. Very slightly soluble in chloroform, ethylalcohol, slightly soluble in dichloromethane and isopropylalcohol, soluble in methyl alcohol. Stored in air tight container, protected from light.

Pharmacokinetic properties ${ }^{(4)}$ :On oral administration it is completely absorbed from gastrointestinal tract and undergoes first pass metabolism in the liver by CYP1 A2,CYP2D6,CYP3A4 enzymes. Peak plasma level is reached after 1.5 hours. Plasma half life 3.9 hours. Bioavailability is $60 \%$. Metabolized by Cyp P450 System. 
Therapeutic uses: Used in management of nausea, vomiting, pain. Already known literature suggests that Ondansetron is more effective than paracetamol in relieving the pain of fibromyalgia, pruritis, alcohol dependent psychiatric disorder.

Adverse effects: Well tolerated drug. Headache, sensation of flushing or warmth, constipation, dizziness are the adverse effects.

\section{Acetyl Salicylic Acid Or Aspirin ${ }^{(5)}$}

Is analgesic, anti inflammatory and antipyretic and inhibitor of platelet aggregation. It inhibits cyclo oxygenase by acetylation of the active site of enzyme and the pharmacological effects of it are due to the inhibition of the formation including prostaglandins, thromboxanes, and prostacyclin.

Pharmacokinetics: Very rapidly absorbed from gastrointestinal tract. Appreciable quantities are found in plasma in less than 30 minutes. Absorption influenced by gastric PH. Rise in PH increases the solubility of aspirin. Distributed through most of the body fluids, transcellular fluids. Readily crosses placental barrier.

The two major pathways of salicylate elimination i.e formation of salicyluric acid and salicyl phenolic glucoronide. Renal clearance of salicylic acid increases markedly with increasing urine PH.

Therapeutic uses: Analgesic, antipyretic, cardioprotective, uricosuric, keratolytic etc.

Adverse effects: ${ }^{(6)}$ Intolerance, gastric erosions, reduces plasma prothrombin level by interfering with action of vitamin $\mathrm{k}$ in the liver, reyes syndrome, salicylism.

\section{Materials And Methods:}

30 Male swiss albino mice weighing 25-30 gm were procured from animal house of osmania medical college, Hyderabad. Ondansetron and Aspirin were obtained from local pharmacy. The experiment was conducted in the department of Pharmacology, Osmania medical college.

Acute toxicity test ${ }^{(7,8)}$ :It was conducted in mice using ondansetron intraperitonially(i.p) in the dosage of $8,16,32$ and $64 \mathrm{mg} / \mathrm{kg}$ body weight.LD50 was found to be $46 \mathrm{mg} / \mathrm{kg}$ body weight. According to the known literature LD50 of aspirin when given Intraperitonially in mice is $160 \mathrm{mg} / \mathrm{kg}$ body weight.

\section{Chemical Method (Intra Peritonial Injection Of .6\% Acetic Acid)}

Writhing response ${ }^{(9)}$ induced with acetic acid was described by WITKIN et al(1961). Writhing is described as a stretch, torsion to one side, drawing of a hind leg, retraction of abdomen and opisthotonous, so that the belly of the mouse touches the floor. The animals which showed writhing movements were grouped into 3 batches each consisting of 8 . To one group standard drug aspirin is given intraperitonially in doses of $25,75,125 \mathrm{mg} / \mathrm{kg}$ body weight. To second group Ondansetron suspension in water is given intraperitonoially in doses of $0.5,1.5$, and $2.5 \mathrm{mg} / \mathrm{kg}$ body weight. The third group is the control group to which $1 \mathrm{ml}, 2 \mathrm{ml} / 100 \mathrm{mg}$ body weight of normal saline was injected intraperitonially equal in volume to tab aspirin solution given intraperitonially to first group. Half an hour after drug administration the three groups are given $0.6 \%$ acetic acid intraperitonially. Results observed after one hour. Experiment repeated with different graded doses of drugs.

\section{Mechanical Method(Tail Clip Method)}

The experimental procedure followed was that of BIANCHI and FRANCESCHINI(1954).After taking weights of mice an artery clip covered with thin rubber tube was applied to the base of the mouse tail for ten seconds. Those mice which made a continuous effort to dislodge the clip by biting it with in 10 seconds were selected and grouped into two batches of 8 each. The time at which the mice made response due to application of clip to the tail was noted down for each mouse before giving any drug ${ }^{(10)}$. Tab ondansetron and tab aspirin were crushed into fine powder and water was added to make a suspension. Two groups of animals were tested with a tail clip and results were noted at $30 \mathrm{mts}$ after giving $25 \mathrm{mg}, 75 \mathrm{mg}, 125 \mathrm{mg}$, of aspirin intraperitonially(i.p) $0.5 \mathrm{mg}, 1.5 \mathrm{mg}$, and $2.5 \mathrm{mg}$ of ondansetron i..p was given. The time taken for positive response that is continuous effort to dislodge the clip was recorded.

\section{Radiant Heat Method(Analgesiometer)}

This experiment was carried out on mice by means of analgesiometer ${ }^{(11)}$ devised by M.LGujaral.(Techno)Male albino mice weighing between 25 to 30 gms were chosen for preliminary screening. They were divided into groups of eight each. All the animals were tested for noting the latent period of the withdrawal of tail after exposure to the radiant heat from the red hot wire of the analgesiometer. The current was adjusted. A flick of tail of animal in response to radiant heat stimulus was noted before and 30 minutes after administration of drugs in different doses and the difference is taken as the reaction time. The animal would with draw or lift its tail away from the wire when pain was felt due to thermal radiation. The difference between increased reaction time and normal reaction time is due to elevation of pain threshold. The drugs aspirin and 
Comparative study of analgesic effect of Ondansetron and Aspirin in experimentally induced ....

ondansetron given i.p in two different groups of mice. The animals were tested and results were noted at $30 \mathrm{mts}$ after giving aspirin and ondamsetron i.p. Difference of reaction time before and after giving drugs was noted.

Statistical analysis was done through student $\mathrm{t}$ test ${ }^{(12)}$.Mean, standard deviation, standard error and $\mathrm{p}$ value ${ }^{(13)}$ were calculated. $\mathrm{p}<.05$ was considered statistically significant.

\section{Results}

The different methods used to produce pain models in animals were chemical, mechanical, radiant heat method.

Table-I (Chemical Method) Percentage Of Mice Showing Analgesic Responses With Ondansetron And Aspirin At Different Dosages In Different Groups By Writhing Method In Comparision With Control.

\begin{tabular}{|c|c|c|c|c|}
\hline DRUGS & NO.OF ANIMALS & DOSE IN $\mathrm{mg} / \mathrm{kg}$ & $\begin{array}{l}\text { NO.OFANIMALS WITH } \\
\text { ANALGESIC EFFECT }\end{array}$ & $\begin{array}{l}\text { \%OF } \\
\text { SHOWING ANALGESIC } \\
\text { EFFECT }\end{array}$ \\
\hline ONDANSETRON & $\begin{array}{l}8 \\
8 \\
8\end{array}$ & $\begin{array}{l}0.5 \\
1.5 \\
2.5\end{array}$ & $\begin{array}{l}0 \\
2 \\
8\end{array}$ & $\begin{array}{l}0 \\
25 \% \\
100 \%\end{array}$ \\
\hline ASPIRIN & $\begin{array}{l}8 \\
8 \\
8\end{array}$ & $\begin{array}{l}25 \\
75 \\
125\end{array}$ & $\begin{array}{l}0 \\
4 \\
8\end{array}$ & $\begin{array}{l}0 \\
50 \% \\
100 \%\end{array}$ \\
\hline $\begin{array}{l}\text { NORMAL SALINE } \\
\text { (CONTROL) }\end{array}$ & 8 & $2 \mathrm{ml}$ & 0 & 0 \\
\hline
\end{tabular}

Table-II (Chemical Method) Effect Of Test Drugs On Writhing Syndrome In Mice

\begin{tabular}{|l|l|l|}
\hline DRUG & MEAN WRITHING EPISODES & \% INHIBITION OF WRITHING EPISODES \\
\hline CONTROL & 45.7 & 0 \\
\hline ONDANSETRON & 18.4 & $58.78 \%$ \\
\hline ASPIRIN & 25.2 & $48.9 \%$ \\
\hline
\end{tabular}

$\mathrm{P}<.001$,HIGHLY SIGNIFICANT

Table-III (Mechanical Method)Showing The Responses Before And 30 Minutes After Administration Of Ondansetron I.P For Different Dosages And Significance By Tail Clip Method In Mice.

\begin{tabular}{|c|c|c|c|c|c|c|}
\hline & DOSE IN $\mathrm{mg} / \mathrm{kg}$ & MEAN & $\begin{array}{l}\text { STANDARD } \\
\text { DEVIATION }\end{array}$ & $\begin{array}{l}\text { DIFFERENCE } \\
\text { BETWEEN } \\
\text { MEAN }\end{array}$ & $\begin{array}{l}\text { STANDARD } \\
\text { ERROR }\end{array}$ & p-VALUE \\
\hline $\begin{array}{l}\text { BEFORE } \\
\text { AFTER }\end{array}$ & $\begin{array}{l}0 \\
0.5\end{array}$ & $\begin{array}{l}0 \\
3\end{array}$ & $\begin{array}{l}0 \\
0\end{array}$ & 0 & 0 & - \\
\hline $\begin{array}{l}\text { BEFORE } \\
\text { AFTER }\end{array}$ & $\begin{array}{l}0 \\
0 \\
1.5\end{array}$ & $\begin{array}{l}3 \\
15.04\end{array}$ & $\begin{array}{l}0 \\
0.3204\end{array}$ & 12.04 & 0.1133 & NS \\
\hline $\begin{array}{l}\text { BEFORE } \\
\text { AFTER }\end{array}$ & $\begin{array}{l}0 \\
2.5\end{array}$ & $\begin{array}{l}3 \\
40.21\end{array}$ & $\begin{array}{l}0 \\
0.2915\end{array}$ & 36.79 & 0.1031 & $0.047(\mathrm{~S})$ \\
\hline
\end{tabular}

NS-NOT SIGNIFICANT,S-SIGNIFICANT

Table-IV (mechanical method)showing the responses before and 30 minutes after administration of aspirin i.p for different dosages and significance by tail clip method in mice.

\begin{tabular}{|c|c|c|c|c|c|c|}
\hline & DOSE IN $\mathrm{mg} / \mathrm{kg}$ & MEAN & $\begin{array}{l}\text { STANDARD } \\
\text { DEVIATION }\end{array}$ & $\begin{array}{l}\text { DIFFERENCE } \\
\text { BETWEEN } \\
\text { MEAN }\end{array}$ & $\begin{array}{l}\text { STANDARD } \\
\text { ERROR }\end{array}$ & p-VALUE \\
\hline BEFORE & 0 & 3 & 0.1195 & 6.95 & 0.2645 & NS \\
\hline AFTER & 25 & 10.05 & 0.2268 & & & \\
\hline BEFORE & 0 & 3.44 & 0.1996 & 41.44 & 0.1822 & $0.052(\mathrm{~S})$ \\
\hline AFTER & 75 & 44.88 & 0.4432 & & & \\
\hline BEFORE & 0 & 3.55 & 0.1604 & 96.70 & 0.4013 & $0.025(\mathrm{~S})$ \\
\hline AFTER & 125 & 100.25 & 1.1674 & & & \\
\hline
\end{tabular}

NS-NOT SIGNIFICANT,S-SIGNIFICANT

Table-V (Radiant Heat Method)Showing The Responses Before And 30 Minutes After Administration Of Ondansetron I.P For Different Dosages And Significance By Analgesiometer In Mice.

\begin{tabular}{|l|l|l|l|l|l|l|}
\hline & DOSE IN mg/kg & MEAN & $\begin{array}{l}\text { STANDARD } \\
\text { DEVIATION }\end{array}$ & $\begin{array}{l}\text { DIFFERENCE } \\
\text { BETWEEN } \\
\text { MEAN }\end{array}$ & $\begin{array}{l}\text { STANDARD } \\
\text { ERROR }\end{array}$ & p-VALUE \\
\hline BEFORE & 0 & 3 & 0 & 0 & 0 & - \\
\hline
\end{tabular}


Comparative study of analgesic effect of Ondansetron and Aspirin in experimentally induced ....

\begin{tabular}{|l|l|l|l|l|l|l|}
\hline AFTER & 0.5 & 3 & 0 & & & \\
\hline BEFORE & 0 & 3 & 0 & 2.7 & 0.1052 & NS \\
AFTER & 1.5 & 5.7 & 0.1852 & & & \\
\hline BEFORE & 0 & 3 & 0 & 12.04 & 0.1133 & NS \\
AFTER & 2.5 & 15.04 & 0.3204 & & & \\
\hline
\end{tabular}

NS-NOT SIGNIFICANT.

Table-VI (Radiant Heat Method)Showing The Responses Before And 30 Minutes After Administration Of Aspirin I.P For Different Dosages And Significance By Analgesiometer In Mice.

\begin{tabular}{|c|c|c|c|c|c|c|}
\hline & DOSE IN mg/kg & MEAN & $\begin{array}{l}\text { STANDARD } \\
\text { DEVIATION }\end{array}$ & $\begin{array}{l}\text { DIFFERENCE } \\
\text { BETWEEN } \\
\text { MEAN }\end{array}$ & $\begin{array}{l}\text { STANDARD } \\
\text { ERROR }\end{array}$ & p-VALUE \\
\hline BEFORE & 0 & 5 & 0 & 0 & 0 & \\
\hline AFTER & 25 & 5 & 0 & & & \\
\hline BEFORE & 0 & 4.97 & 0.227 & 1.51 & 0.1089 & $0.052(\mathrm{~S})$ \\
\hline AFTER & 75 & 6.48 & 0.226 & & & \\
\hline BEFORE & 0 & 5.07 & 0.245 & 4.27 & 0.1475 & $0.031(\mathrm{~S})$ \\
\hline AFTER & 125 & 9.3 & 0.226 & & & \\
\hline
\end{tabular}

NS-NOT SIGNIFICANT,S-SIGNIFICANT

Graph-I(Chemical Method)

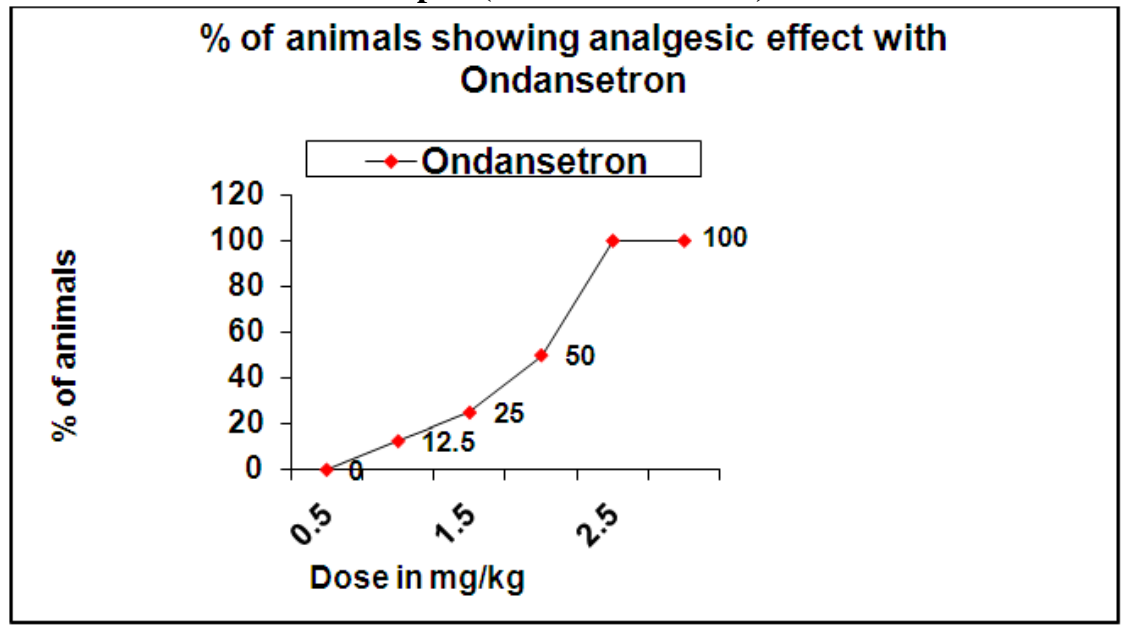

Graph-II(Chemical Method)

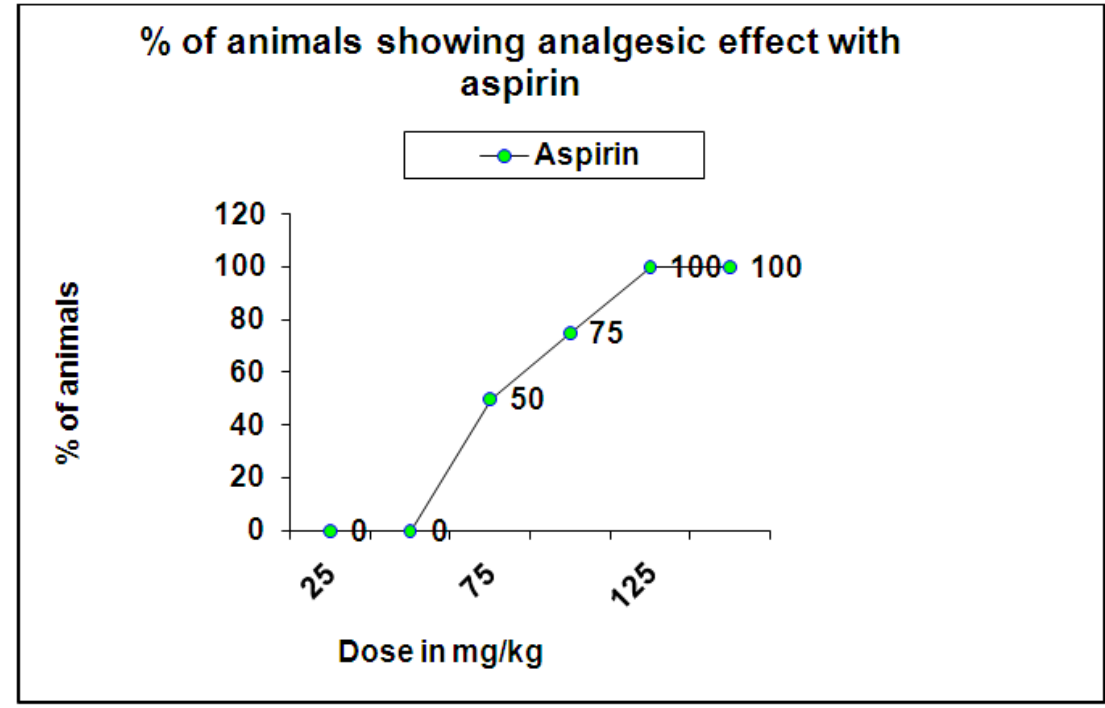



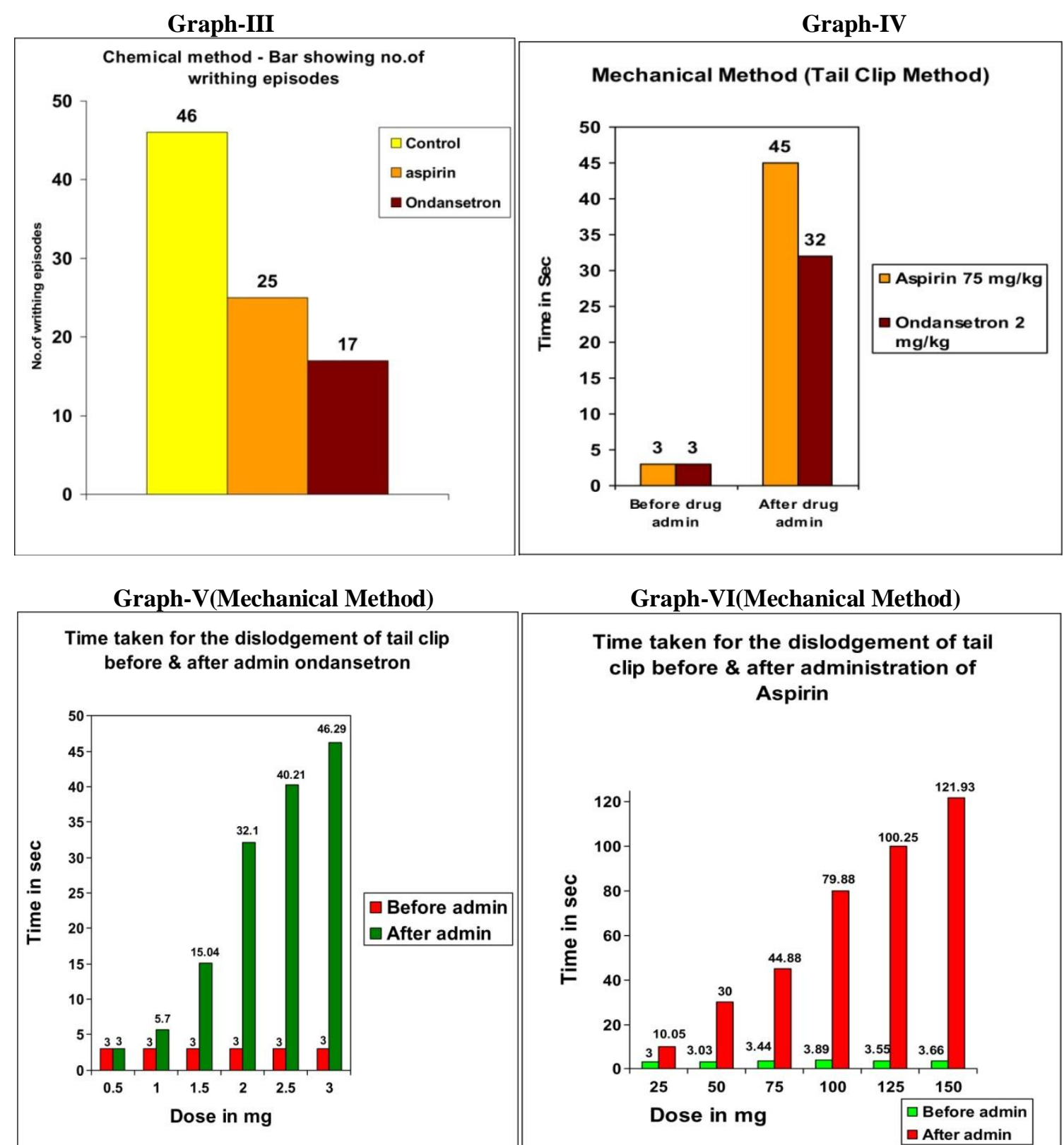

Graph-VI(Mechanical Method)
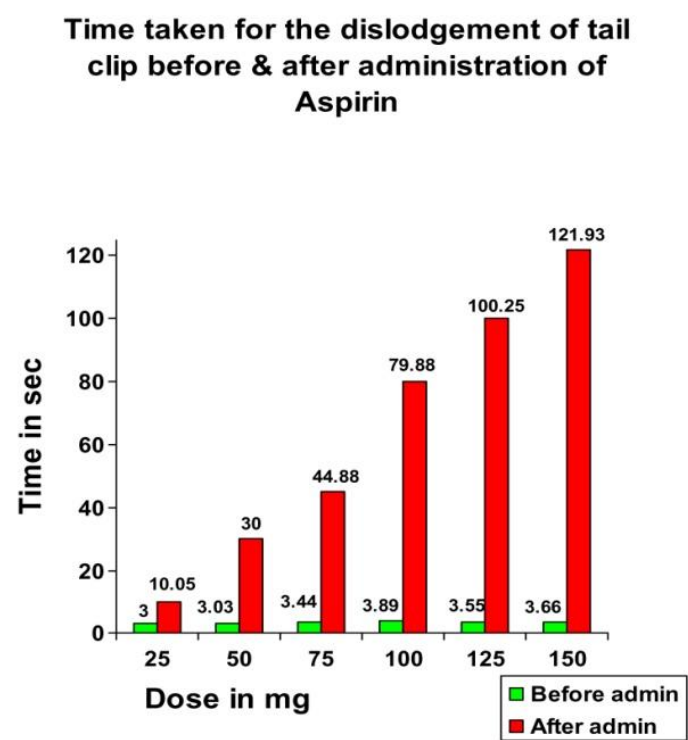

\section{Discussion}

Ondansetron,a synthetic carbazole, is a serotonin $5 \mathrm{HT}_{3}$ receptor antagonist ${ }^{(14)}$ was tested for its analgesic property and compared with aspirin. It is known that the $\mathrm{NK}_{1}$ expressing neuron in lamina I to III of the spinal cord are associated with the perpetuation of pain after a peripheral injury and that these neurons can be selectively inhibited by the $5 \mathrm{HT}_{3}$ antagonist ondansetron. Case report by Gary McCleane et al suggest that analgesia can be achieved by the human clinical use of ondansetron in subjects with chronic neuropathic pain with an absence of side effects. The analgesic activity of ondansetron and aspirin were tested by chemical, mechanical and thermal methods.

\section{Chemical method}

The chemical method (writhing response) is considered to be specific for week analgesics. ${ }^{(15,16)}$ Ondansetron in the dose of $2.5 \mathrm{mg} / \mathrm{kg}$ showed analgesic activity in $100 \%$ of animals(mice) \{GRAPH-I \}aspirin in the dose of $125 \mathrm{mg} / \mathrm{kg}$ showed analgesic activity in $100 \%$ of animals(mice) \{TABLEI,GRAPH-II .Ondansetron $2.5 \mathrm{mg} / \mathrm{kg}$ showed $58.78 \%$ inhibition of writhing episodes in mice while aspirin $125 \mathrm{mg} / \mathrm{kg}$ showed $48.9 \%$ inhibition of writhing episodes in mice which were induced by $0.6 \%$ acetic acid i.p. There is no inhibition of writhing episodes with normal saline.(TABLE-II,GRAPH-III).p $<0.001$,statistically highly significant. Ondansetron has better analgesic activity than aspirin in chemically induced pain models(mice) ${ }^{(17)}$ 
Comparative study of analgesic effect of Ondansetron and Aspirin in experimentally induced ....

Mechanical method (tail clip method)

When ondansetron $2.5 \mathrm{mg} / \mathrm{kg}$ was given to mice standard deviation was 0.2925 and $\mathrm{p}$ value was 0.047 which is statistically significant(TABLE-III,GRAPH-V). When aspirin $125 \mathrm{mg} / \mathrm{kg}$ was given to mice standard deviation was 1.1674 and $p$ value was 0.025 which is statistically significant.(TABLE-IV,GRAPH-VI).GRAPHIV shows comparative study of analgesic effect in mice by ondansetron $(2 \mathrm{mg} / \mathrm{kg})$ and aspirin $(75 \mathrm{mg} / \mathrm{kg})$. Aspirin showed more analgesic effect than ondansetron in this method.

\section{Radiant heat method(analgesiometer)}

This method was done by using analgesiometer. Even with $2.5 \mathrm{mg} / \mathrm{kg}$ of ondansetron in mice ,there was no analgesic activity(TABLE-V).With $125 \mathrm{mg} / \mathrm{kg}$ of aspirin in mice, standard deviation was 0.226 and $\mathrm{p}$ value was 0.031 which is statistically significant(TABLE-VI)

The potency of an analgesic drug vary with substance, species of animal, ${ }^{(18)}$ route of administration, ${ }^{(19)}$ type of method employed.

\section{Conclusion}

In chemically induced method(i.p of $.6 \%$ of acetic acid)the ondansetron showed superior analgesic effect than that of aspirin.In mechanical method(tail clip method) aspirin showed more analgesic activity than ondansetron. By thermally induced pain model(radiant heat method)aspirin showed analgesic effect while there was no analgesic effect with ondansetron. However the above experiments gave us an idea about the analgesic property of ondansetron. To obtain the final assessment, large scale clinical trials ${ }^{(20)}$ are necessary.

\section{Acknowledgement}

We thank department of pharmacology ,osmania medical college,Hyderabad,for their inspiring guidance.

\section{References}

[1]. Harper,D. (2001). "Online Etymology Dictionary: Analgesia". Retrieved December 3, 2012.

[2]. Hinz B, Cheremina O, Brune K (2008). "Acetaminophen (paracetamol) is a selective cyclooxygenase-2 inhibitor in man.". The FASEB journal: official publication of the Federation of American Societies for Experimental Biology 22(2): $383-$ 390. doi:10.1096/fi.07-8506com. PMID 17884974.

[3]. WHO Model List of EssentialMedicines". World Health Organization. October 2013. Retrieved 22 April 2014

[4]. US Food and Drug Administration. (2012). FDA Drug Safety Communication: New information regarding QT prolongation with ondansetron (Zofran). Retrieved fromhttp://www.fda.gov/Drugs/DrugSafety/ucm310190.htm

[5]. "Zorprin, Bayer Buffered Aspirin (aspirin) dosing, indications, interactions, adverse effects, and more". Medscape Reference. WebMD. Retrieved 3 April 2014.

[6]. Sørensen HT; Mellemkjaer L; Blot WJ; Nielsen, Gunnar Lauge; Steffensen, Flemming Hald; McLaughlin, Joseph K.; Olsen, Jorgen H. (2000). "Risk of upper gastrointestinal bleeding associated with use of low-dose aspirin". Am. J. Gastroenterol. 95 (9): $2218-$ 24.doi: 10.1111/j.1572-0241.2000.02248.x. PMID 11007221

[7]. Ghosh MN (1984). Fundamentals of experimental pharmacology. 2ndedn. Scientific Book Agency, Calcutta, p. 154-157

[8]. Crook MA (2006). Clinical Chemistry and Metabolic Medicine. 7thedn.Hodder Arnold, London, p.426.

[9]. Dannerman PJ. In: Monitoring of analgesia in anesthesia and analgesia in laboratory animals. Kohn DK, Sally K, Wixson B, White WJ, John G, editors. USA: Academic Press; 1977. pp. 83-99. Ch. 6.

[10]. Bianchi C, Franceschini J (1954) Experimental observationson Haffner's method for testing analgesic drugs. Br JPharmacol 9:280284

[11]. D'Amour FE, Smith DL . A method fordetermining loss of pain sensation. JPharmacol Exp Ther . 1941.72:p.74-79

[12]. Zimmerman, Donald W. (1997). "A Note on Interpretation of the Paired-Samples t Test". Journal of Educational and Behavioral Statistics 22 (3): 349-360. doi:10.3102/10769986022003349.JSTOR 1165289.

[13]. Goodman, SN (1999). "Toward Evidence-Based Medical Statistics. 1: The P Value Fallacy.". Annals of Internal Medicine 130: 995-1004.doi:10.7326/0003-4819-130-12-199906150-00008.PMID 10383371.

[14]. King, Frank D.; Jones, Brian J.; Sanger, Gareth J. (1993). 5-Hydroxytryptamine-3 Receptor Antagonists. CRC Press. pp. 23.ISBN 978-0-8493-5463-2.

[15]. Conaghan PG (June 2012). "A turbulent decade for NSAIDs: update on current concepts of classification, epidemiology, comparative efficacy, and toxicity". Rheumatol. Int. 32 (6): 1491-502. doi: 10.1007/s00296-011-2263-

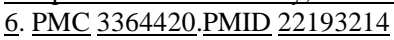

[16]. Brunton, L; Chabner, B; Knollman, B (2010). Goodman and Gilman's The Pharmacological Basis of Therapeutics (12th ed.). New York: McGraw-Hill Professional. ISBN 978-0-07-162442-8.

[17]. Mogil JS, Davis KD, Derbyshire SW (2010) The necessity of animal models in pain research. Pain 151: 12-17 doi:10.1016/j.pain.2010.07.015.PubMed/NCBIGoogle Scholar

[18]. Sharon L. Vanderlip (2001). Mice: Everything About History, Care, Nutrition, Handling, and Behavior. Barron's Educational Series. pp. 38-. ISBN 978-0-7641-1812-8. Retrieved 22 April 2013.

[19]. Quinn DI Wodak A Day RO (1997). "Pharmacokinetic and Pharmacodynamic Principles of Illicit Drug Use and Treatment of Illicit Drug Users". Clinical Pharmacokinetics (Springer) 33 (5): 344-400. doi:10.2165/00003088-199733050-00003. PMID 9391747.

[20]. PhRMA. February 2007 Drug Discovery and Development. 